\begin{tabular}{|c|c|c|c|c|}
\hline Submission & Review Process & Revised & Accepted & Published \\
\hline $08-03-2020$ & $20-04$ s/d 20-05-2020 & $28-06-2020$ & $30-06-2020$ & $30-06-2020$ \\
\hline
\end{tabular}

Jurnal Studi Sosial dan Politik, Vol. 4, No. 1, June 2020 (67-86)

ISSN 25978756

e ISSN 25978764

Jurnal Studi Sosial dan Politik Published by: FISIP Universitas Islam Negeri Raden Fatah Palembang

\title{
Tracking the Deadlock of the Struggle on Inclusive Citizenship Study of the Disability Movement in DIY Province
}

\author{
Isnenningtyas Yulianti \\ Komisi Nasional Hak Azazi Manusia RI \\ Email: tyas.yulianti@gmail.com
}

\begin{abstract}
Inclusive citizenship is currently being fought for by groups that care about vulnerable groups. In Indonesia the ideals of inclusive citizenship are also fought for persons with disabilities. So far, persons with disabilities have become excluded social groups. The disability movement is intensely voicing inclusive citizenship through the struggle to form regulations that can bring changes to the lives of persons with disabilities, starting from the CRPD Convention, the Disability Persons Act, then local regulation of Disabilities. This paper will use the concept of structuration Giddens and confronting the disability movement in fighting for inclusive citizenship with efforts from the government to capture the issue of inclusive citizenship. The Disability Movement in Yogyakarta Province is a model of the movement that has succeeded in fighting for regional regulations for persons with disabilities. This movement was considered successful when the national movement struggled for the Law on Persons with Disabilities experiencing a deadlock, but in the process the disability movement has not been able to process the issue of inclusive citizenship in its struggle, and the local government as if it does not understand what the disability movement is trying to achieve. Instead of making realize the ideals of inclusive citizenship, the Disability Movement is trapped in an exclusive movement model. The Movement Model in DIY Province is an example in the struggle for inclusive citizenship which was initially considered successful but later suffered a deadlock.
\end{abstract}


Keywords: inclusive citizenship; disability; disability movement

\begin{abstract}
Abstrak
Kewarganegaraan inklusif saat ini banyak diperjuangkan oleh kelompok-kelompok yang peduli terhadap kelompok-kelompok rentan. Di Indonesia cita-cita kewarganegaraan inklusif juga diperjuangkan bagi penyandang disabilitas. Sejauh ini, penyandang disabilitas telah menjadi kelompok sosial yang dipinggirkan. Gerakan disabilitas secara intens memperjuangkan kewarganegaraan inklusif melalui perjuangan untuk membentuk peraturan yang dapat membawa perubahan kehidupan bagi penyandang disabilitas. Mulai dari Konvensi CRPD, Undang-Undang Penyandang Disabilitas, kemudian peraturan daerah tentang Disabilitas. Paper ini akan menggunakan konsep strukturasi Giddens dan membandingkan gerakan disabilitas dalam memperjuangkan kewarganegaraan inklusif dengan upaya dari pemerintah untuk menangkap isu kewarganegaraan inklusif. Gerakan Disabilitas di Provinsi Yogyakarta adalah model gerakan yang telah berhasil memperjuangkan peraturan daerah untuk perlindungan dan pemenuhan hak penyandang disabilitas. Gerakan ini dianggap berhasil ketika gerakan nasional memperjuangkan Undang-Undang Penyandang Disabilitas mengalami kebuntuan, tetapi dalam prosesnya gerakan disabilitas belum mampu membawa kewarganegaraan inklusif dalam perjuangannya, dan pemerintah daerah seolah-olah tidak mengerti apa yang ingin dicapai oleh gerakan disabilitas. Alihalih mewujudkan cita-cita kewarganegaraan inklusif, Gerakan Disabilitas terjebak dalam model gerakan eksklusif. Model Gerakan di Provinsi DIY adalah contoh dalam perjuangan untuk kewarganegaraan inklusif yang pada awalnya dianggap berhasil tetapi kemudian mengalami kebuntuan
\end{abstract}

Kata Kunci: kewarganegaraan inklusif; disabilitas; gerakan disabilitas

\title{
INTRODUCTION
}

This study was conducted to represent at the advocacy process of the disability movement in fighting for inclusive citizenship rights which is began with encouragement of the Regional Regulation on the Protection of Persons with Disabilities in the Yogyakarta Province. The promising initial process ultimately failed to change the situation, because it was stuttering in mapping and reaching layers of struggle that had to be carried out. Inclusive citizenship means that all citizens must be treated as citizens, whatever they are. Its citizenship must not be compromised by its weaknesses / strengths, including persons with disabilities. In this study, disability is assessed as an issue that requires multiple layers of treatment. However, due to the lack of understanding of 
the layers of the problem, the struggle for inclusive citizenship fought for by the disability movement seemed to be progressive, but eventually it failed.

For some reason, this study refers to events in Yogyakarta. In the Province of Yogyakarta, an interesting phenomenon took place, particularly in developing the character of citizenship in a more inclusive direction. Inclusivity meant here is to ensure that even citizens with disabilities are treated equally with other citizens. The advocacy process that has taken place here has succeeded in bringing forth what is referred to as the "Disability Law", that is, a law that was initiated in order to improve the rights and welfare of persons with disabilities. Although improvements have been made, awareness of the rights and fulfillment of the welfare of persons with disabilities has not yet fully entered the awareness of policy makers and other regional apparatuses. What happened was the development of half-hearted inclusiveness.

Since the ratification of the CRPD (Convention on the Right of Persons with Disabilities), under the Law No. 19 of 2011 concerning Ratification of the Convention on the Right of Persons with Disabilities, The disability rights activists increasingly have a legal basis in advocating government policies so that persons with disabilities obtain rights as citizens. Proposals for changes in laws and regulations are actively voiced by groups of people with disabilities and human rights activists. The drafting of the Yogyakarta Province Regulation on Persons with Disabilities is one of them. Behind the stipulation of this regulation there are interesting political processes to be revealed and picked for practical and scientific purposes.

As studies on citizenship in general, this study examines more the relationship between "the state" with "citizens". In this concept, persons with disabilities must be included in the conceptualization of state development. In other words, citizenship is a contested concept. The struggle in upholding this concept took place simultaneously with the work of the forces of inclusion and exclusion. Through this struggle, the conceptualization of traditional citizenship which tends to accentuate the inclusion side turns out to be ignorant of exclusivity towards the disabled. (Lister, 2008) Ironically, this is precisely the view that is considered normal. It is this view, which in terms of citizenship has a serious "flaw" because it separates the views between exclusion and inclusion. Although legally the rights of persons with disabilities in the province of Yogyakarta have been protected, this does invite new questions about how the perception of bureaucracy in issuing the policy. This perception shows whether disability is considered as a citizen or is still a social welfare problem.

The Local Regulation on Persons with disabilities was born ahead of the National Law which is being discussed in the House of Representative. Substantially, this regulation also changed the concept of handling that was based on "charity" to "protection" and "fulfillment of rights". However, it must be noted that this change takes place within the "under" of the Law on Persons with Social welfare Problems that has not been revoked. This means that the Ministry of Social 
Affairs or the Social Service as a State Institution mandated to deal with Persons with Disabilities still uses the concept of People with Social Welfare Problems which is includes persons with disabilities.

Since the change in disability data from Health Indicator to social welfare indicator, disability issues have become a social sector problem. According to Law number 11 of 2009 concerning Social Welfare and Decree of the Minister of Social Affairs number 82 / HUK / 2005 concerning the Duties and Work Procedures of the Ministry of Social Affairs states that the focal point in handling the problems of persons with disabilities in Indonesia is the Ministry of Social Affairs $^{1}$ of the Republic of Indonesia. The task is more directed towards social service and rehabilitation efforts, namely the process of finalization and development to enable persons with disabilities to be able to carry out their social functions appropriately in people's lives. In addition, the Ministry was also given a mandate by Law number 4 of 1997 concerning Disabled for the provision of social assistance and maintenance of the level of social welfare for persons with disabilities. (Irwanto, 2010)

The Local Regulation on Persons with Disabilities in the province of DIY appears as a guideline in other regions because the content of Human Rights is so thick in it. However, the success in the drafting of the regulation was not followed by successful implementation steps. The enactment of the Regional Regulation on Persons with disabilities is an effort to provide improvements in the protection and fulfillment of the rights of persons with disabilities. In the DIY Disability Law, the concept of charity that used to exist in Law Number 4 of 1997 concerning Disabled Persons has been replaced by the principle of Human Rights, as the concept of Rights in the UNCRPD (United Nations Convention on the Right Person with Disability). However, these efforts should be followed by actions in the implementation of programs and other policies that follow the contents of the regulation. However, as previously noted, the PMKS Law (Law on Persons with Social Welfare Problems) is still in force and places persons with disabilities as social problem, so that the Regional Regulation on Persons with Disabilities comes with the principle of Human Rights, but with the old concept that people with disabilities are People with social Welfare Problems. In this study will explore the struggle of the disability movement in fighting for disability regulations. What is the advocacy process in developing the inclusiveness of citizens with disabilities in the Province of DIY? And how do activists open up, discover, and exploit opportunities for the establishment of inclusive citizenship? 


\section{RESEARCH METHOD}

This paper is an evaluation of the disability movement that carries change in the Special Region of Yogyakarta by bringing the basis of inclusive citizenship for policy changes for persons with disabilities. This Paper also notice the significance of the Disability Perda in promoting inclusive citizenship in the Province of DIY. To be able to see whether inclusive citizenship can be carried out properly, it is necessary to look at social practices that occur from day to day as well as changes that occur from day to day through the power of discipline, then the social practice is carried out requires legitimacy that can be seen through structures run by the government regions and efforts or encouragement from the people who make changes.

Using Giddens' theory in structuration theory, the scope of dualism or opposition is redefined as duality. Specifically, dualism between individuals and society is reimagined as a duality between agency and structure. Giddens focused his main study on the development of a series of concepts that functioned to describe the meaning of "individual" as a reflective agent, by linking reflexivity with positioning and face-to-face.

Giddens continues to recognize the fact that structure always limits action. Restricting actions or subordinating agencies can be through three structural derivatives, namely the structure of significance, the structure of domination (authoritative and allocative), and the structure of legitimacy. First, the structure of signification which involves the symbolic scheme, significance, designation, and discourse. Second, the structure of domination which includes a scheme of control over people (politics) and goods / things (economy). Third, the structure of justification or legitimation which involves the normative regulatory scheme, which is revealed in the legal system.

Following the Giddens structuration flow, the issue of persons with disabilities in DIY Province can be seen as follows: The Interaction structure group will see how the Structure and Agents work together in driving change for persons with disabilities in the province of DIY. The evaluation aspect will be seen from the communication between actors, the construction of knowledge on the meaning of disability, and the implementation of sanctions if there are violations of the perda. The evaluation will then look at how the communication between the agent and the structure built in the process leads to the change. And how the tread of struggle is carried out. The Intermediate

Facility Structure cluster is used to see how discourse develops and the distribution of knowledge can be carried out in order to encourage this change. And what changes have been made. Cluster Significance structure to see whether the regulations that are encouraged are legitimate and significant to be called the success of inclusive citizenship. 
Duality always involves intermediate means. For example, the disability movement presupposes a "frame of interpretation" of disability discourse. The change in discourse from charity to empowerment and equality. So it is clear that the word disability should be used in the official language and used to change the nomenclature of the bureaucratic structure in the OPD and government structures.

In the duality of the structure of domination and the practice of control, see whether the authorized official, ie the Governor, requires all OPDs to replace term with disability instead of "cacat" in each program, and carry out disability mainstreaming in their programs or policies accompanied by budget allocations for the program. In social practice the three clusters are interrelated with each other, the structure of significance in social practice will include the structure of dominance and legitimacy. Domination refers to the asymmetrical relationship at the level of structure, while power concerns the capacities involved in social relations that occur in social practice. Power is not a symptom associated with the system, but rather an inherent capacity in the actor, therefore it always involves transformative capacity. Meanwhile there are two kinds of resources involved in forming the structure of domination, namely allocative and authoritative. For example, the mention of "cacat" or "defects". In the scheme, the duality between structure and actor takes place as follows. First, seen from the structure of the significance of people with disabilities, they are considered as disabled who do not empower themselves. Persons with disabilities are also interpreted by the community as people who no longer have self-esteem, have no value, are imperfect, with all kinds of other meanings given by the community. This stigma has been going on for a long time and continues to apply in society, this is because socially and culturally persons with disabilities are not given the space of mobility. Second, the structure of domination or domination, persons with disabilities experience dominance both in terms of the dominance of authorization over people manifested in politics, social and culture as well as the dominance of the allocation of goods that is manifested in the economic order. Persons with disabilities have been made to "depend" on their families, communities and countries because people with disabilities have no choice at all.

The following articles are used as a reference for this research, such as Article of Dara $\mathrm{Z}$. Strolovitch, in a book entitled, "Affirmative Advocacy, Race, Class, and Gender in Interest Group Politics". ${ }^{2}$ Strolovich underlined the relationship between NGO advocacy and public participation. Strolovich also mention In that article that in a part of political domination, the winner will take over all political systems. Interest groups are considered important in representing minority voices. 
But it is formal organizations that are considered effective in advocating for the interests of constituents, especially if these interests call for social change.

Strolovich found that the interests of intersectionality of disadvantaged subgroups were not well represented as "people" from other subgroups. In other words, advocacy groups do not promote the interests of disadvantaged subgroups. Strolovitch concluded that advocacy groups inadvertently continued to marginalize the disadvantaged subgroup.

Ruth Lister argues that one reason why citizenship is a contested concept that it operates together as a force for both is inclusion and exclusion. The theory of traditional citizenship tends to emphasize the inclusionary side and largely ignores exclusion. One way to think about inclusive citizenship, within the boundaries of the nation state, is to take the main components of citizenship, membership and ownership; rights and obligations that flow from that membership; and equality of status, and opinions that they must apply to all citizens are alike.

In the book titled Citizenship and Vulnerability, Angharad E. Beckett clearly illustrates various theories of citizenship and social movement theory. In his study Angharad used "disability as a case study, contextualized the approach and understanding of vulnerability in seeing" disability"with the experience of disability that impacted the theory of citizenship and social movements. Angharad suggested leaving political differences or points of view, but began to bridge or connect between groups of individuals with different identities. Angharad's idea was to develop citizenship as a pro-active involvement.

In this article, my position is the same as that of Angharad E Beckett. This research sees that inclusive citizenship can be realized by proactive involvement and by leaving existing differences. During this time the disability movement was solved in terms of issues and background of the movement. Many disability organs were formed in the New Order era with structures close to the government, so many disability issues are not represented. The Organizations that were born into the reform movement grew with diverse issues. However, it must be noted that the extent of active involvement can have an impact on change. The disability movement gives a new nuance in social movements in the community. The disability movement in carrying out local regulations with disabilities can unite the movement by leaving the background of each movement. However, what is different from Angharad E. Beckett's article is that the Disability Movement is unique because its movement model seems "exclusive" but can encourage policies for change and improvement of the rights of persons with disabilities in the province of DIY. What makes distinguishes is, in this article author not only sees the success of the movement of people with disabilities in carrying out local regulations, but also their failure to realize the ideals of inclusive citizenship that are in the regulations, and tracks where the deadlock with using structuration theory. 


\section{RESULTS AND DISCUSSIONS}

\section{Advocacy as a"Charm" of Movement: Reflections on the Disability Movement Path}

Citizens who were in the assessment of the unconscious do not meet the qualifications, in everyday of relationships, referred to as "penyandang cacat". This terminology were lasted a long time, and continued until the New Order. Their existence is considered not important. Policies and programs never include people with disabilities. In the public's imagination, those who are called "cacat" are only a number of groups of people who are invisible. Therefore, their treatment is based on a spirit of charity.

Expressions of state compassion for citizens are marked by the involvement of the Ministry of Social Affairs. The domain of state responsibility is only a "social" issue, the essence of which is giving compensation or assistance. The government in this case acts to facilitate groups and organizations of persons with disabilities. The program provided is in the form of aids or other charitable programs. The state or government treats persons with disabilities as groups of people who cannot do anything, so it needs to be helped. The contents of the Law made at that time were base on Charity.

Over the years, those group who categorized as "cacat" have received attention from the government to the extent of the policies and programs implemented by the Ministry of Social Affairs. The policies implemented by the Ministry of Social Affairs are carried out through oneway programs, because persons with disabilities cannot provide input on ongoing or future programs.

In the New Order era, organizations with disabilities were very close to power and only prospered the elite. These organizations are also flamboyant because they include their figures as protectors and advisors to their organizations. For example, the Educational Foundation for Children with Disabilities presents the figure of Mrs. Tien Soeharto as the Foundation's Protector. In the end, these organizations were encouraged to support the Group of Work Groups affiliated with President Soeharto at that time. Each congress will be funded by the organization which is then arranged in a congress to produce an agreement to support the Golkar Party.

This condition then create the new form of the disability organization. The new organizations were a group of people who are starting to be disappointed with the existing forms of organization. The results of their critical thinking led to a situation of change and dialogue with other organizations in various sectors. As was done by some of figures in Yogyakarta, some members of organizations with disabilities began to conduct a series of discussions to several campuses with students, groups or other organizations. They discussed the problems of people with 
disabilities by linking the issues that were developing at that time. The formed of organization is not a mass-based structural organization. This organization is more independent and only working on issue-based. For example on environmental issues, women, and agriculture then come up with the issue of citizenship. After all they are citizens and they need new frames to understanding and treating them well.

The openness and renewal of the issue of disability became wider with ideas and issues that developed from the student movement at that time. The student movement in Yogyakarta at that time was heavily influenced by the discourse and issues of social change brought by Mansour Fakih. The closeness of the movement with Mansour Fakih also brought Setya Adi Purwanta one of the figure of disability movement to be involved in other social change issues. This is the beginning of the disability movement in Yogyakarta and getting involved with the issue of social change.

Society were not finished with the stigma and treatment of the state that have "pity" the disabled. The government passed the Social Welfare Act which places people with disabilities as social welfare problems. Law Number 4 of 1997 concerning Penyandang Cacat is very minimal in reference to the protection of the rights of persons with disabilities, both nationally, regionally, and globally, so substantively the material contained in the law is minimal in reference and tends to result from an understanding of people disabilities were limited. As a result, with the development of the time this law is no longer able to provide maximum protection for the rights of persons with disabilities. This can be seen from several realities, such as Law No. 4/1997 contains minimal mainstreaming and respect for the rights of persons with disabilities as part of citizens in general. Meanwhile in the Social Welfare Act, persons with disabilities are included in the category of social problems.

This approach then led to a program in the form of compassion or charity base. So that the program carried out is only in the form of social assistance and rehabilitation and does not consider the rights of persons with disabilities in developing themselves. To support various assistance programs for people with disabilities, the government issued Government Regulation No. 43 of 1998 concerning Efforts to Improve Social Welfare of Persons with Disabilities. As an effort to improve the social welfare of persons with disabilities in accordance with Article 4, it is provided through rehabilitation and social assistance. This is a form of providing protection and maintenance of the level of social welfare directed at people with disabilities to obtain a reasonable standard of living through the Government Regulation.

The revolving discourse in the public arena moves various segments of society to do something. There are a number of actors or agents involved in pushing for the realization of disability regulations in the Province of DIY. The actors involved start from the Disable People Organization (DPO), independent mobilization actors, and persons with disabilities. All of these 
actors are involved in developing and encouraging change movements for the protection and fulfillment of the rights of persons with disabilities in the Province of DIY. The impetus for the preparation of the Provincial Disability Law of DIY was initiated by a group of DPOs who felt the need or urgency for a local regulation that specifically regulates persons with disabilities. The initiation process was carried out by activists who were focused and interested in disability issues in the Province of DIY. They collaborated with the Social Service by emphasizing that local regulations on persons with disabilities are important needed by the regions, especially in the Province of DIY.

These communities or DPOs are, among others, the Institute for the Study and Empowerment of Disabilities for Social Transformation (Dria Manunggal), Women's, Disability and Children Advocacy Centers (SAPDA),SIGAB, Disability Integration and Advocacy Centers (SIGAB), OHANA, Center for Improving Qualified Activity in Live of People with Disabilities (CIQAL).

Those DPO institutions were built or were present before the collapse of the New Order regime in Indonesia. The spirit of protecting and fulfilling human rights for persons with disabilities is important and urgent to be carried out by the state as an institution that should protect every citizen regardless of differences from any aspect. These agents, together with the community of persons with disabilities in the Province of DIY, participated actively in the process of drafting a regulation on Disabilities. For them, it is important that the Province of DIY has a legal-formal rule that protects and fulfills the rights of persons with disabilities that for decades have been marginalized both by the state and by the communities where they are located.

The idea of encouraging local regulations began when all DPOs in Yogyakarta gathered to compile an evaluation of the ratification of the CRPD Convention for the protection of persons with disabilities. In the evaluation evaluation of the implementation of the CRPD, it was stated that the CRPD had not been sufficient to provide protection for persons with disabilities, this was because the CRPD was more a concept that was not yet implemented. Thus, all DPOs in Yogyakarta agreed to follow up by encouraging the Regional Regulation on Persons with Disabilities. The idea was later expanded by inviting Social Services, academics, Local Government and other DPOs. However, the active role of the process is all DPOs in Yogyakarta. Tit for tat, when the local government gave a positive response on that idea.

The process of initiating this local regulation was carried out by the Yogyakarta Provincial Social Service with several activists who were concerned with disability issues at the end of 2010 or early 2011. The drafting process began with the drafting, drawing up detailed draft regulations from article to article, conducting public consultations, and following the discussion in (House of Representatives) DPRD DIY Province. The assertiveness of the Provincial Government of DIY in the form of accommodating and providing space and opportunities for the agenda for the 
preparation of this Disability Perda. While on the other hand, people with disabilities work hard to occupy a position in a wide enough space to open public participation.

The process of the drafting the regulation tends to be quite short. Discussion and rejection of arguments only occur in a few articles of the draft regulation. The spirit of encouraging this local regulation is fully supported by the DPRD who really wants to have a Disability regulation, in the aftermath of the earthquake that struck the DIY Province in 2006 wich caused many deaths and hundreds become disabilities. And the reason why DPRD also support the Draft, because they need legal basis for the programs for many disabilities that affected by earthquake. The Chairperson of the Special Committee for the Drafting local Regulation on Persons with Disabilities at the time stated that the rejection almost did not occur because of the same enthusiasm, namely wanting local regulations that could protect people with disabilities.

The local Regulation on Persons with Disabilities was passed in 2012, but it only came into force in 2014. In addition to being able to implement this regulation, 7 Governor Regulations (Peraturan gubernur/pergub) are required which must be immediately issued. In its development it takes time to advocate for these derivative regulations. In 2012-2014 what happened was a process of negotiation and then the preparation of seven governing decrees. Some academic processes were also prepared, for example in 2014, Regional Development Impelentation Agency or Bappeda together with Pusat Layanan Disabilitas PSLD UIN Sunan Kalijaga or Disability services centre conduct a review of the readiness of the perda. Between 2012 and 2014 also led to intensive discussions related to the preparation and approval of the" Pergub". Each DPO was involved with their respective issues. Sapda helped encourage the Pergub for Special Health Insurance Agency, Driya Manunggal prepared the Pergub for Resource Center for inclusive education. Even though the DPO oversees the approval of these regulations, there are still some contexts in the content of the Governor's regulation that are not in line with the mandate of the local regulations and the expected ideal conditions.

The implementation of the Perda on Persons with Disabilities in its journey raises various problems and obstacles. There are two areas which are often complained or problematic, namely the realization of education and health services for persons with disabilities. As the researchers found, in this regulation there are a few matters relating to the commitment of various institutions or agency to be friendlier with people with disabilities. Disability groups repeatedly submitted reports to the Local Ombudsman institutions regarding the Governor's Decree on inclusive education. The draft is considered far from the spirit of inclusive education in Perda. Also in the field of services still raises several problems. One case that is often complained of by persons with disabilities or families with persons with disabilities is the issue of Special Health Insurance for persons with disabilities that is quite complicated, and impractical. Jamkesus (Jaminan Kesehatan Khusus) as one of the outputs from the Perda on Persons with Disabilities, as expected should be 
a prime facility and priority considering that the programs is related and to help persons with disabilities from health checks and treatment to the provision of assistive devices for persons with disabilities.

The emergence of the Regional Regulation on Persons with Disabilities is very surprising, because this regulation arose when a disability group in nationally discussing to amandments the Law No. 4 of 1997. Disability Perda seemed to emerge suddenly in the midst of twisting the process of encouraging the Disability Bill. The birth of Perda precedes the organic law, making the momentum that the struggle for the rights of persons with disabilities actually get a very large attention from the local government. The emergence of this Perda on Persons with Disabilities was used as a milestone in the joint struggle, for the similar local regulations in each region, So that these could became a driving force for the emerging of the organic law. In the course of the history of the movement, the achievements are inseparable from the popularity of advocacy ideas. Organizing joint steps to make changes, is very keen to be utilized, and the political climate available is very conducive for that. Since then, the activists' struggle has been fixed on the idea of "advocacy" itself. In the next discussion, it will be shown how "advocacy" itself is actually trapping.

\section{New Terminology in Old Meaning Frame: Failure to Build a New Structure}

For years, people with disabilities have lived in social conditions that see them as a group that needs to be pitied because of the perceived inability, physical, and psychological. This condition has implications for the assumption that both persons with disabilities and families with disabilities consider it as a disability or even a curse. The Examples of practices against persons with disabilities that are very discriminating are confinement (pemasungan) in a closed room and minimal access, children with disability not registered their birth certificate and not being recognized on the list of population record. those are such a form of unwilling family with persons with disabilities.

The approach model by seeing that persons with disabilities are "sufferers" is the impact of the current global discourse that places persons with disabilities as diseases. This approach is called a medical model. This approach model places persons with disabilities as personal problems or "personal tragedy". The medical model approach is personal. Through this approach disability is understood as an individual problem. If a person experiences a disability in vision, hearing, or inability to walk is considered as a problem of their own disability. In the medical model, people with disabilities have problems that are ultimately addressed through assistance from government programs and charitable activities, where people who have disabilities are dependent people. The dominance of this discourse has put people with disabilities in a position to continue to be pitied and discriminated against 
The medical logic model has brought Indonesia, implemented a charity-based approach in every program for people with disabilities. The state through the local government (still) places persons with disabilities as weak vulnerable groups so it needs to be pitied by giving cash assistance. This positive role in the long term tends to strengthen the position of persons with disabilities as a weak group and needs to be empowered. In other words, this positioning does not provide significant space for persons with disabilities to build the movements and potentials that they actually have, instead are increasingly dependent on the compassion of the state and strengthen their position as vulnerable groups.

The New Order policy are perpetuated in Law Number 4 of 1997 concerning Disabled Persons. This law is used as a basis for making programs and policies. The contents of this law are considered very disappointing by some groups of people with disabilities. The concept that is carried out is very charitable or compassionate, so that it does not have empowerment for persons with disabilities. The disability group itself is trying to replace the term. Until finally, a figure in Yogyakarta Mansour Fakih introduced a new concept by replacing the mention of "Penyandang cacat" as Difable. This concept also brought a change of approach in disability matters. This approach is better known as the social approach or Social Model. In the Social Model the emphasis is more on disability matters that are no longer seen as a disease or health concern. This model is to respond to their problems and experiences in the health and welfare approach offered by the state through social assistance which makes them socially isolated and oppressed. Through social models, disability is understood as an unequal relationship in society where the needs of persons with disabilities are often given less or without consideration. Persons with disabilities are ignored by the fact that they are excluded from participation in society because of obstacles from physical, organization form and attitude.

The term "penyandang cacat" and "difable" apparently did not bring significant changes to the way public interpretation of persons with disabilities. Various practices of discrimination still occur in both the public and domestic sphere itself. The Law on Persons with Disabilities which is expected to be able to raise the dignity of the lives of persons with disabilities turns out to be even more confining them into a discriminatory and compassionate space. Therefore, when Indonesia took part in the International Convention on the Rights of Persons with Disabilities or CRPD, and in order to encourage the ratification of UNCRPD, several figures gathered to initiate the conversion of the mention of disabled persons into disabilities. The meeting was initiated by Komnas HAM by inviting all interested stakeholders. The meeting was held on January 8-9, 2009, in the form of a seminar on "Workshop on Terminology of Persons with Disabilities". The results of the discussion assigned the small team as a framers and set the term Disability as a substitute term for Persons with Disabilities. The term people with disabilities appears precisely in the discussion of small teams that were not previously present at the workshop meetings. The term 
"disabled" has been decided to refer to the term that is used widely and internationally, namely persons with disabilities. The experts choose the use of the term with the definition of people who have physical, mental, intellectual or sensory limitations in the long term that in interaction with the environment and the attitude of the community can meet obstacles that make it difficult to participate fully and effectively based on equal rights. The institutionalization of the term Disability as a substitute for the term Disability can be the basis for facilitating the drafting of academic drafts of the draft law on the ratification of the CRPD. The interpretation scheme for persons with disabilities, using the choice of words - which is the earliest foundation in the meaning process becomes important and urgent to be carried out by activists and persons with disabilities. As explained by Giddens, through the choice of words or language and repeated usage has implications for the process of meaning of something. Language through mention not only functions as a medium of communication but also as an effective means or apparatus that conveys messages, confirms messages, and internalizes those messages.

Since 2010, the term of dissability officially has been promoted as a substitute for the term "cacat". In its journey, both the National Commission on Human Rights and persons with disabilities activists understand very well, that the biggest work is how to change the perspective and meaning of the wider community to people with disabilities, not merely on changing the mention of the defective or "cacat", abnormal, sick to the disabled person to become "person with disability".

Since the Process, DPO at Yogyakarta start to move and advocacy the local regulation. The advocacy process carried out by the disability movement in DIY Province has not yet run optimally. This is because the new disability movement can advocate until the legislation is passed, but to advocate and oversee its implementation is still far from expectations. This is because Agents are trapped in disability issues which narrow their space. Agents as holders of information about actual issues, theories, thus making local regulations more acceptable to the structure to be ratified immediately. However, the process was not continued in controlling its implementation. The disability movement in DIY and in Indonesia in general, still uses the old logic. That the protection and fulfillment of disability rights is not yet the maximum is a state problem that is incompetent in managing disability matters. This makes the movement tangible to actions that continue to criticize government policy. Instead of fighting for and mainstreaming the issue of disability on the issue of stigma, the disability struggle is trapped in the issue of legal legality which is considered to provide equality guarantees.

Basically, the movement has internal problems between communications with DPO's, which are structural in nature, namely chairman to member. So that the information does not reach the lower level of membership, it makes the synergy fail to build an agenda setting in disability mainstreaming. 
This research proves that the agency struggle in empowering structures fails when the issue being fought is unable to turn social norms into legitimacy. This failure occurred because the movement was half-cooked which is became a tendency for advocacy practices, especially on the issue of disability. The work of the advocacy movement on the issue of disability only revolves around the communication level. Ideally the movement can carry out advocacy not only at the level of communication, but to mobilize power and emphasize sanctions to strengthen the legitimacy of the issue. Therefore the new movement designs offered are: The Bottom up Movement, and have high solidarity with other issues.

\section{The irony of the Movement and the "False Victory" of the Law on Persons with Disabilities} Local regulations (perda) promoted by the DPO network have not or do not show maximum results. Initially, the enactment of a local regulation was a step in the success of the disability movement in the Province of DIY, but in reality a small victory that resulted in a local regulation has not yet become an integral part of the protection and fulfillment of the rights of persons with disabilities. The regional regulation seems to be a monument to success that has not yet been followed up in a better direction. Various problems arise and are considered as obstacles in the implementation of Perda Persons with Disabilities, in addition to internal disability issues themselves.

The Provincial Regulation of Persons with Disabilities in Yogyakarta needs to be highly appreciated. This success was a milestone that became the debut of success for the achievement of the struggle for the agenda of other inclusive citizenship enforcement movements. As we know that the Local Regulation on Persons with Disabilities in the Province of DIY has triggered the development of the issue of amending regulations and efforts to protect disability in other regions, outside DIY. In addition, the victory of the local regulation on disability also brings new enthusiasm for the struggle to push for changes to the Law on Persons with Disabilities. However, what needs to be underlined is the disability victory in the fight for local regulations, the consistency must be maintained so that the implementation can be measured continuously. The Social Service and relevant government agencies that carry and are directly involved in the implementation of this regulation are institutions that play an active role in the effort to realize the regulation. In addition to the regional government, the local regulation drafting movement was also encouraged and fully supported by the legislative body in Yogyakarta Province. This institution wants an immediate regulation to be formed to support the work of board members and the government in an effort to uphold inclusive citizenship, especially after the province was struck by the earthquake in 2006.

Aside from being supported by the role of the government and legislature, the success of this regional regulation cannot be separated from the struggle and cooperation between DPOs with the community and with other NGOs. They were actively involved in the fight for together from 
the first issue of the need for regulatory legal instruments for the protection of persons with disabilities. The development of the issue of disability was triggered by the large flow of information about disability after the ratification of the International Convention on PwDs. This convention has a big positive influence on the development of issues, terminology, and approaches in looking at disability matters. Social and human rights approaches are more emphasized in viewing and implementing programs for people with disabilities.

In addition to the ratification of the International Convention on PwDs, the flow of human rights discourses and the era of decentralization also influenced the locomotive of fresh air for the development of the issue. The spirit of upholding human rights and the emerging awareness can arouse and encourage disability groups to achieve their rights through the Regional Regulation on Persons with Disabilities.

The most encouraging thing is the substance and content contained in this regulation can accommodate various interests of persons with disabilities. The articles in this regulation support and are in line with the mandate and spirit of the CRPD. Although some articles proposed by activists and persons with disabilities have changed when they are in the Legal Bureau of the Provincial Government of DIY, there is substantially no significant change that ignores the rights of persons with disabilities in the local regulation. These changes occur due to limited knowledge in policy makers about discourse and understanding of persons with disabilities both in society and in state institutions.

At the beginning of the formulation of the Law on Persons with Disabilities, the power to encourage this regulation was also born of the people's representatives, who were very concerned about the condition of people with disabilities after the earthquake in DIY. That way, support does not only come from disability groups but also from policy makers. Even though on the way, the strength of that support has weakened as the legalization of the perda of persons with disabilities. The drafting of the Regional Regulation on Persons with Disabilities takes a long time and requires a lot of energy. Debate, public dialogue, and movement emerged in an effort to mainstream this issue to the public until it was passed by the legislature in a product of the law. The supporting team wants a complete, comprehensive, and ideal draft perda. This is due to the fact that the regulation is expected to become a high legal umbrella that protects and respects the fulfillment of the rights of persons with disabilities which so far tend to be structurally marginalized. However, to do that, it requires the reconstruction of new ways of thinking in favor of the protection and fulfillment of the rights of persons with disabilities as stipulated in the Regional Regulation on Persons with Disabilities. Not all policy makers in the executive and legislative domains have the same understanding as activists and people with disabilities regarding the needs of fulfilling the rights of persons with disabilities. This then becomes an obstacle in the process of drafting and even implementing a Regional Regulation on Persons with Disabilities in the Province of DIY. 
One thing that makes this policy easy to push for is the urgent need for provincial government to deal with people with disabilities that have increased in number after the earthquake. So that this is easily communicated with persons with disabilities and policy makers. In addition, the notion of inclusiveness is also in line with the provincial government's program that really wants to realize an inclusive region.

Ironically, up to three years of implementation of the Regional Regulation on Persons with Disabilities in the Province of DIY, there has not been any visible change in the direction that is aspired together to realize an inclusive society. Of the various programs carried out by the DIY provincial government on disability, many ordinary people do not know or do not understand about disability. by the community. For example, the implementation of Jamkesus or special health insurance which is intended for persons with disabilities is not yet able to be understood by some disabilities themselves and the community at large.

The disability movement itself is trapped in the construction of change by encouraging various policies relating to persons with disabilities. They consider that the issuance of new regulations is the goal in achieving a disability movement, so that at present the movement only focuses on the movement to encourage the issuance of the Disability Law, and the regional regulations on disability protection. The assumption is that with this regulation, change can occur into empty dreams when the movement does not manifest in a real movement in upholding an inclusive movement.

Inclusiveness, what is meant is not merely a dichotomy of disability and non-disability issues. However, the disability movement is currently still trapped in building inclusiveness for disabilities only. So it is difficult to measure the achievement of an inclusive movement for disability which only deals with disability issues.

As a social movement DPOs still regard the state or government as a structure that oppresses people with disabilities and places disabilities as weak and deserve to be oppressed. This is due to the construction of negative / skewed / marginalized meanings of disability socially, politically, culturally, economically, which take root for decades or even hundreds of years in society. It is not denied, that the policy on disability so far has influenced the construction Identifying which structural problems are oppressing is wrongly carried out by DPOs so that the ideals of changing the structure of the perspective of disability have not been successful, even though local regulations and laws on persons with disabilities already exist in several regions in Yogyakarta.

When local regulations are passed what changes for people with disabilities? The answer is almost nothing other than loading pairs (beautifying) signs on the sidewalk for people with disabilities, especially in the Malioboro shopping area of Yogyakarta. 
Furthermore, and most obviously there is no specific and large budgeted budget to fulfill the mandate of the local regulations of persons with disabilities. Regional governments, and existing DPOs such as the Social Service and Health Services cannot be said to have successfully implemented the ideals of the perda because the implementation form is still minimal and insignificant.

That way, the presence of a local regulation with a disability can be said to be a false victory because it is not an actual victory. The regional regulation is only a release document that the Yogyakarta regional government already has a disability regulation as a form of participation in realizing inclusive citizenship which is their big goal. In fact, local regulations can be used as a starting point in making changes to the structure of community meanings that are biased towards people with disabilities. Unfortunately, when the regulation was passed, the DPO was satisfied and celebrated the victory without: (1) monitoring or following up on the implementation of the regulation; (2) moreover aware of and carry out sharp criticism of the structure of meaning that is biased towards disability in a society that is rooted for so long, not only by the state or government. There are several things that must be underlined, that the stagnation of achieving citizenship is inclusive because the disability movement is wrong in identifying the source of the main problems. The movement forgets that the meaning structure that considers disability as a disease is a construction of thought that has taken root for decades, so that the movement should move on to the structural scheme, namely reducing or removing stigma. After the passage of the Regional Regulation on Disability, the hegemony that people with disabilities is not a disease, or sick people who must be helped, does not necessarily change the construction of that thinking. The main problem does not lie with the state, but moreover is the issue of public awareness and awareness of "new" awareness about people with disabilities. So far the new movement has been able to change the terminology of disability into disability, but has not been able to expand the new awareness. This is where the stagnation of citizenship achievement in inclusion takes place.

\section{CONCLUSION}

The disability movement as with other social movements assumes established agents and movement structures as factors. But the relation between the actor and the structure here is not dualism but is called duality. That the actors and structures of social movements mutually assume and are interrelated. Actors in this case refer to disability groups while established structures are rules and resources that are formed from and shape social practices that are repeated. In this case, persons with disabilities face the stigma and worldview that has taken root for decades. The stigma or perspective of society is the social structure of the cluster of significance regarding the mention and meaning of persons with disabilities. However, because the practice of compassion has been carried out for years, it has become a structure of domination which involves mastery over people. 
People tend to think with awareness that is built for decades. The assumption that people with disabilities are negative and full of stigma makes it difficult for people with disabilities to appear in public spaces. Achievements that occur such as online motorbike taxi, and job seeker-specific web disabilities only indicate that they have difficulty accessing work, which means that stigma continues to exist while the struggle for the disability movement is only a matter of producing policies.

The struggle of the disability movement in this case misplaced the state as the sole holder of power, so the main target was blamed on the state. In fact, the main problem that must be changed is the problem of stigma and meaning about disability that is rooted. It is not entirely a problem of the disability movement, because the memory of the struggle of the movement in the New Order period contributed to that memory. Thus, making a similar stagnation also occurs in movement in general.

Because of the cross-section of misinterpretation and identification of wrong problems, the law is not "nothing" and has never moved anywhere. The movement sees the State as an oppressive threat, while the State tries to change but does not know where it wants to change. While the community is still with the structure of the old thought that people with disabilities are sick and various other negative stigma.

\section{ACKNOWLEDGMENT}

This manuscript is the essence of the thesis text, entitled "The Superficiality of Inclusive Citizenship: A Case for the Protection and Fulfillment of the Rights of Persons with Disabilities in the Province of DIY." This thesis has been accounted for before the thesis session on July 312017 to obtain a master's degree in the Department of Politics and Government, Concentration on Democracy and Human Rights, at the Faculty of Political Science, Gadjah Mada University. Thanks to Mr. Prof.Dr. Purwo Santoso, M.A, who provided full guidance in completing this Thesis. Thank you also to the manager of the Power Welfare Democration (PWD) scholarship for providing this study and research scholarship. 


\section{REFERENCES}

Angharad E. Beckett, (2006), Citizenship and Vulnerability, Dissability and Issues of Social and Political Engagement, Palgrave Macmillan

Carson, Grant. "The Social Model of Disability," Scottish Information Forum (SAIF), 2009. http://www.dpiap.org/resources/pdf/Social_Model_Disability_2011_04_22.pdf

Dara Z. Strolovitch, (2007)Affirmative Advocacy, Race, Class, and Gender in Interest Group Politics, The University of Chicago Press

Fuad, Bahrul, (2011) "Revitalizing the Disability Movement." Journal of Women 69

Giddens, Anthony, (1979), Central Problems in Social Theory. London: Macmillan, 1979. . (2010), Structural Theory, Basics of Forming Social Structure of Society. Yogyakarta: Student Library

_., (1984), The Constitution of Society: Outline of the Theory of Structuration. Cambridge: Polity Press,

Irwanto, Prof, and Eva Kasim, (2010) "Analysis of the Situation of Persons with Disabilities in Indonesia: A Desk Review." Disability Study Center, Faculty of Social and Political Sciences UI

Lister, Ruth, (2008), "Inclusive Citizenship, Gender and Poverty: Some Implications for Education for Citizenship." Loughborough University, Citizenship Teaching and Learning 4, no. 1

Moeloeng, Lexy J, (2004) Qualitative Research Methodology. Bandung: Youth Rosdakarya

Purwanta, Setya Adi, (2002) "Breaking Fear Into Strength." In Advocacy Stories in Indonesia, March. Insist Press

Ritzer, George, and Douglas J Goodman, (2007) Theories of Modern Sociology. Edited by Alimandan. Jakarta: Kencana 